\title{
Levels of Selected Metals in Ambient Air PM10 in an Urban Site of Győr, Hungary
}

\author{
A. Szabó Nagy, Zs. Csanádi, J. Szabó \\ Széchenyi István University, Physics and Chemistry Department \\ Egyetem square 1, 9026 Győr, Hungary \\ E-mail: nszaboa@sze.hu
}

Abstract: The aim of this study was to assess the ambient concentrations of some selected trace metals $(\mathrm{Pb}, \mathrm{Cd}$ and $\mathrm{Ni})$ and the metalloid $\mathrm{As}$ in the PM10 aerosol fraction in an urban site of Györ, Hungary in 2011. The results show that the study area has excellent air quality with respect to metal(loid)s during the four sampling periods. However, the annual average concentration of PM10 indicates a polluted area. The PM10 concentrations were higher in heating season than in summer time. The levels of PM10 and trace elements determined were compared with other cities located in Hungary and around the world.

Keywords: PM10, trace metals, ambient air, air quality

\section{Introduction}

Air quality is an important issue for public health, the economy and the environment. Poor air quality as a result of air pollution is a major environmental health risk, contributing to respiratory disease, cardiovascular disease, and lung cancer. In addition to the health effects, air pollution has considerable economic impacts, cutting short lives, increasing medical costs, and reducing productivity through lost working days across the economy. Particulate matter with an aerodynamic diameter smaller than 10 $\mu \mathrm{m}$ (PM10) is considered to be a reliable indicator for possible health effects due to fine particles in ambient air. It consists of a complex mixture of solid and liquid particles of organic and inorganic substances suspended in the air. Although metal-bearing aerosols constitute a small fraction of the PM10 mass, the exceeding concentration and/or longterm exposure to metals could cause severe toxic effects on human health. Thus, measurement of metal concentration levels in inhalable particles is important in determining their potential impacts on human health [1-3].

Metal-bearing aerosols in the ambient atmosphere are produced by various anthropogenic and natural sources. Combustion of fossil fuels and wood, exhaust emission from vehicles, industrial activities, energy production, construction and waste incineration are known to be anthropogenic sources, while volcanic activity, winderoded soil dusts, forest fires, and sea salt spray may contribute to natural metal-bearing aerosols $[1,3]$. Vehicle traffic is a potential source of $\mathrm{Cd}, \mathrm{Pb}, \mathrm{Mn}$ and $\mathrm{Ni}$ as a result of 
fuel combustion and the wearing of brakes, tires, and other components [4]. The $\mathrm{Pb}$ emission has decreased due to the introduction of unleaded fuels. However, increasing environmental concentrations of platinum group elements $(\mathrm{Pt}, \mathrm{Pd}, \mathrm{Rh})$ from catalytic converters has been reported worldwide. Emissions from coal burning power plants are a potential source for $\mathrm{As}, \mathrm{Cd}, \mathrm{Cr}, \mathrm{Pb}$ and $\mathrm{Ni}$ while local ceramic and metal-processing facilities could emit a wide variety of trace metals and metalloids [5].

The aim of this work was to give an overview about the levels of some selected trace metals $(\mathrm{Pb}, \mathrm{Cd}$ and $\mathrm{Ni})$ and the metalloid As in the PM10 aerosol fraction in an urban area of Győr (Hungary) with high traffic density during the year 2011. The levels of PM10 and trace elements determined in our study were compared with air quality standards and with some published data of other cities.

\section{Experimental}

\subsection{Study area}

Györ $\left(47^{\circ} 41^{\prime} 02^{\prime \prime} \mathrm{N}, 17^{\circ} 38^{\prime} 06^{\prime \prime} \mathrm{E}\right)$ is the most important city in the northwest area of Hungary - halfway between Wien, Bratislava and Budapest - situated on one of the important roads of Central Europe. The city is the sixth largest in Hungary, and one of the seven main regional centres of the country. The number of inhabitants is about 128,500 . Győr is a dynamically developing city due to its good geographic situation and as an emphasized centre in automotive industry. It has become one of the largest economic, industrial and traffic areas of Hungary. The monitoring site is located at the junction of Tihanyi Árpád street and Ifjúság boulevard (Fig. 1).

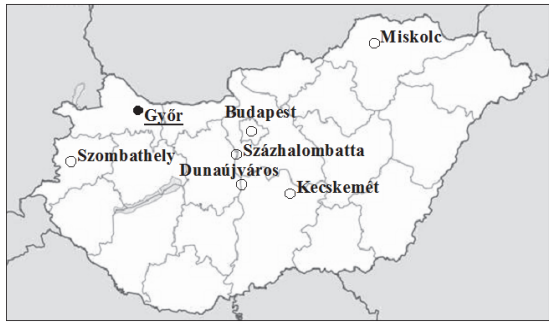

Figure 1. The location of Györ, Hungary and the sampling site in Györ. Some selected other Hungarian stations are also marked, about which this study includes some concentration data

\subsection{Sampling and chemical analysis}

The concentrations of PM10 aerosol fractions and PM10 bound trace metal(loid)s were measured and samples were collected in every third month at 14 day intervals, continuously for 24 hours in 2011 at the monitoring site of Györ. A Digitel High Volume DHA80 (Digitel Elektronik AG, Switzerland) sampler [6] was used for 
collection ambient aerosol particles, which were chemically analysed later. This equipment is considered to be equivalent to the requirements of the European Standard (EN 12341) for sampling PM10 matter [7]. Samples are taken onto high purity Advantec QR-100 quartz fibre filters (size: $150 \mathrm{~mm}$ diameter) for a period of $24 \mathrm{~h}$ at a flow rate of $30 \mathrm{~m}^{3} / \mathrm{h}$ into a container with about $700 \mathrm{~m}^{3}$ volume capacity. The air flow rate can be established with a pump and controlled with an air flow meter.

Before and after sampling, the filters were conditioned during $48 \mathrm{~h}$ at $20 \pm 1{ }^{\circ} \mathrm{C}$ and $50 \pm 5 \%$ relative humidity. The particle total mass was determined by weighing of the sampling filters before and after sampling and the PM10 concentration calculated from the weighted mass on the filter and the sampling volume. This DHA-80 equipment has a container of 15 filters mounted in filter holders and they are changed automatically to the flow position. After the sampling, the filters were wrapped in aluminium foil separately and stored cooled until chemical analysis.

The concentrations of trace metal(loid)s ( $\mathrm{Pb}, \mathrm{Cd}, \mathrm{As}$ and $\mathrm{Ni}$ ) in the PM10 aerosol fraction were measured by graphite furnace atomic absorption spectroscopy (SOLAAR MQZ, Unicam Ltd., Cambridge, UK) equipped with Zeeman and deuterium background correctors, a graphite furnace GF9 and an autosampler. One half of the filter was cut by a ceramic scissor and the sample was treated with $15 \mathrm{~mL}$ aqua regia and digested at temperatures up to $210{ }^{\circ} \mathrm{C}$ for $20 \mathrm{~min}$ using a CEM Mars 5 microwave. The resulting solution was filtered and diluted to $100 \mathrm{~mL}$ with distilled water. A $20-\mu \mathrm{L}$ volume of the sample was injected into the graphite tube. The sample analysis was conducted in accordance with the MSZ EN 14902:2006 Hungarian standard method procedure [8].

\section{Results and discussion}

\subsection{Particulate matter concentrations}

Table 1 gives an overview of the mass concentrations of PM10 as well as the measured trace elements in PM10 at the urban site of Györ in 2011. Fig. 2 shows the average concentrations and standard deviations of PM10 during the different sampling periods. The PM10 concentrations ranged from 11 to $119.14 \mu \mathrm{g} / \mathrm{m}^{3}$. The highest concentration was detected in the sampling of November. Concentrations of PM10 exhibit large variability during the sampling periods. The PM10 concentrations were higher in heating season than in summer time.

Table 1. Concentrations of PM10 and the measured trace metal(loid)s at the urban site of Györ during different sampling periods in 2011

\begin{tabular}{|l|c|c|c|c|c|}
\hline & & \multicolumn{4}{|c|}{ Trace elements $\boldsymbol{n g} / \boldsymbol{m}^{3}$} \\
\cline { 3 - 6 } \multicolumn{1}{c|}{ Sampling period } & $\boldsymbol{P M ~ 1 0 ~} \boldsymbol{\mu g} / \boldsymbol{m}^{3}$ & $\boldsymbol{P b}$ & $\boldsymbol{C d}$ & $\boldsymbol{A s}$ & $\boldsymbol{N i}$ \\
\hline I. 16 February - 1 March & $46.59-110.68$ & $11.11-40.75$ & $0.2-0.73$ & $0.25-1.21$ & $1.03-19.53$ \\
\hline II. 4-17 May & $15.39-29.44$ & $2.95-17$ & $0.28-1.34$ & $0.28-1.04$ & $2.22-5.86$ \\
\hline III. 1-14 August & $11-29.1$ & $1.34-7.08$ & $0.05-0.53$ & $0.26-6.64$ & $3.13-8.64$ \\
\hline IV. 1-15 November & $42.6-119.14$ & $7.53-24.81$ & $0.19-0.57$ & $0.24-1.32$ & $1.23-5.91$ \\
\hline
\end{tabular}




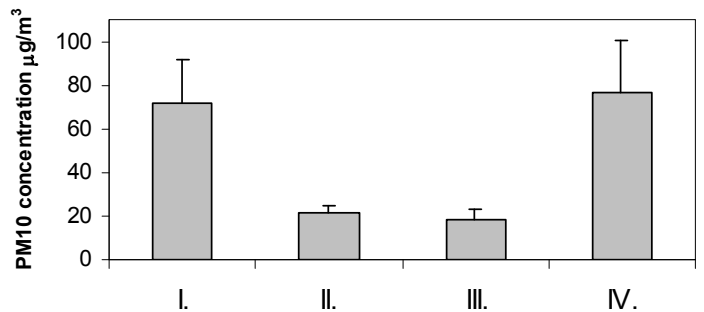

Figure 2. PM10 concentrations at the urban site of Györ during the four sampling periods in 2011

\subsection{Trace metal and arsenic concentrations}

The trend of trace metal(loid) levels at the urban site of Györ in 2011 was found in decreasing order of $\mathrm{Pb}>\mathrm{Ni}>\mathrm{As}>\mathrm{Cd}$. The concentration of $\mathrm{Pb}$ showed the maximum value of $40.75 \mathrm{ng} / \mathrm{m}^{3}$ whereas Cd showed the lowest concentration of $0.05 \mathrm{ng} / \mathrm{m}^{3}$ (Table 1). Overall, the measured trace elements typically amount to about $0.04 \%$ of the total mass of the PM10 fraction in the Györ atmosphere. Fig. 3 illustrates the temporal trend of trace element concentrations during the four sampling periods.
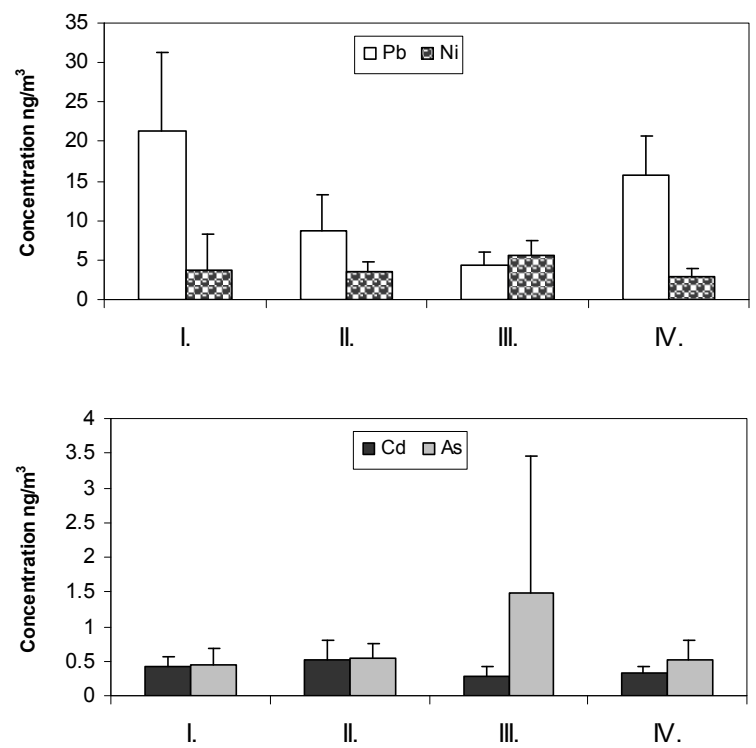

Figure 3. Lead, nickel, cadmium and arsenic concentrations in PM10 at the urban site of Györ during during the four sampling periods in 2011

Higher average mass concentrations of $\mathrm{Pb}$ were found in winter samples than in samples collected in non-heating seasons. The As concentrations were higher in summer due to the two highest concentrations $\left(6.64\right.$ and $\left.4.96 \mathrm{ng} / \mathrm{m}^{3}\right)$ detected in the third sampling period. However, no significant temporal trend was observed for $\mathrm{Ni}$ and $\mathrm{Cd}$. 
The wide range of obtained data for concentration of $\mathrm{Ni}$ in the first sampling period can be explained by the result of only one sample. Excluding the maximum value of 19.53 $\mathrm{ng} / \mathrm{m}^{3}$, the Ni level in the first sampling period was less than $5 \mathrm{ng} / \mathrm{m}^{3}$.

\subsection{Comparison with air quality standards}

Humans can be adversely affected by exposure to air pollutants in ambient air. The European Union (EU) and the Hungarian air quality standards as well as the Hungarian air quality index (AQI) used in this study are summarised in Table 2.

The annual average mass concentration of PM10 $\left(47.43 \mu \mathrm{g} / \mathrm{m}^{3}\right)$ slightly exceeded the EU and the equivalent Hungarian guideline value $\left(40 \mu \mathrm{g} / \mathrm{m}^{3}\right)$. This limit is 2 times higher than the World Health Organization (WHO) air quality guideline value for PM10 $\left(20 \mu \mathrm{g} / \mathrm{m}^{3}\right)$ [2]. The annual average concentrations of each trace element $(\mathrm{Pb}, \mathrm{Cd}, \mathrm{As}$ and Ni) observed for Györ were below the permitted levels. The AQI results show that the study area has excellent air quality with respect to metal(loid)s. However, the annual AQI for PM10 indicate a polluted area. The comparison of the 24-hour PM10 concentrations with the 24-hour AQI values show acceptable, polluted or heavily polluted results in heating season, while indicate excellent or good air quality in the samplings of spring and summer.

Table 2. Air quality standards and index for PM10 and the measured trace elements

\begin{tabular}{|c|c|c|c|c|c|c|c|}
\hline \multirow[b]{2}{*}{ Pollutant } & \multirow[b]{2}{*}{$\begin{array}{c}E U \\
\text { standard } \\
{[3]}\end{array}$} & \multirow[b]{2}{*}{$\begin{array}{c}\text { Hungarian } \\
\text { standard } \\
{[9]}\end{array}$} & \multicolumn{5}{|c|}{ Quality index [10] } \\
\hline & & & $\begin{array}{c}1 . \\
\text { Excellent }\end{array}$ & $\begin{array}{c}2 . \\
\text { Good }\end{array}$ & \begin{tabular}{|c|}
3. \\
Acceptable
\end{tabular} & $\begin{array}{c}4 . \\
\text { Polluted }\end{array}$ & $\begin{array}{c}5 . \\
\text { Heavily } \\
\text { polluted }\end{array}$ \\
\hline $\begin{array}{l}\text { PM10 (24-hour } \\
\text { average) } \mu \mathrm{g} / \mathrm{m}^{3}\end{array}$ & 50 & 50 & $0-20$ & $20-40$ & $40-50$ & $50-90$ & $90-$ \\
\hline $\begin{array}{c}\text { PM10 (annual } \\
\text { average) } \mu \mathrm{g} / \mathrm{m}^{3}\end{array}$ & 40 & 40 & $0-16$ & $16-32$ & $32-40$ & $40-80$ & $80-$ \\
\hline \multicolumn{8}{|c|}{ Trace elements $^{(\text {a) }}$ (annual average) ng/m ${ }^{3}$} \\
\hline $\mathrm{Pb}$ & 500 & 300 & $0-120$ & $120-240$ & $240-300$ & $300-600$ & $600-$ \\
\hline $\mathrm{Cd}$ & $5^{(\mathrm{b})}$ & 5 & $0-2$ & $2-4$ & $4-5$ & $5-10$ & $10-$ \\
\hline As & $6^{(\mathrm{b})}$ & 10 & $0-4$ & $4-8$ & $8-10$ & $10-20$ & $20-$ \\
\hline $\mathrm{Ni}$ & $20^{(\mathrm{b})}$ & 25 & $0-10$ & $10-20$ & $20-25$ & $25-50$ & $50-$ \\
\hline
\end{tabular}

\subsection{Comparison with other cities}

Figs. 4 and 5 compare Győr PM10 and metal(loid) concentrations with results from other Hungarian cities (see also Fig. 1) [10]. The annual average PM10 concentrations exceeded the EU limit in some Hungarian cities in 2011. The exposure limit excess is probably due to the traffic and domestic heating, collectively [3]. The highest 24-hour concentration $\left(183.3 \mu \mathrm{g} / \mathrm{m}^{3}\right)$ was detected in an urban/traffic area of Budapest [10]. The air quality for PM10 in the different Hungarian cities was acceptable or polluted. However, the AQI for trace elements were excellent in all Hungarian cites. The $\mathrm{Pb}, \mathrm{Cd}$ and As levels were the highest in the industrial area of Miskolc. The annual average 
concentration of Ni was the highest in Györ compared to the other Hungarian cities, which may be explained by the local emission sources.

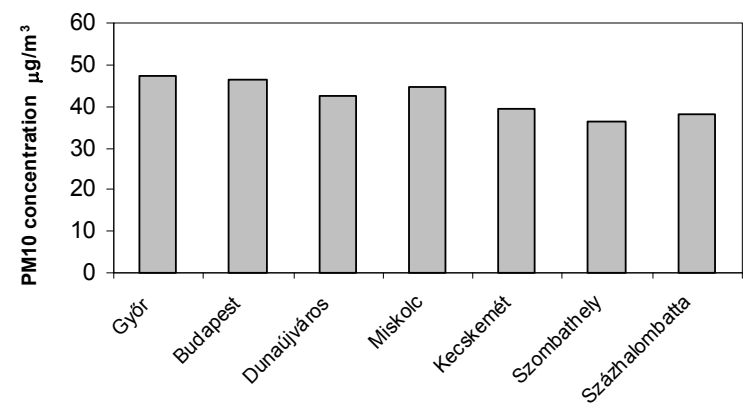

Figure 4. PM10 annual average concentrations observed for Györ with other Hungarian cities in 2011
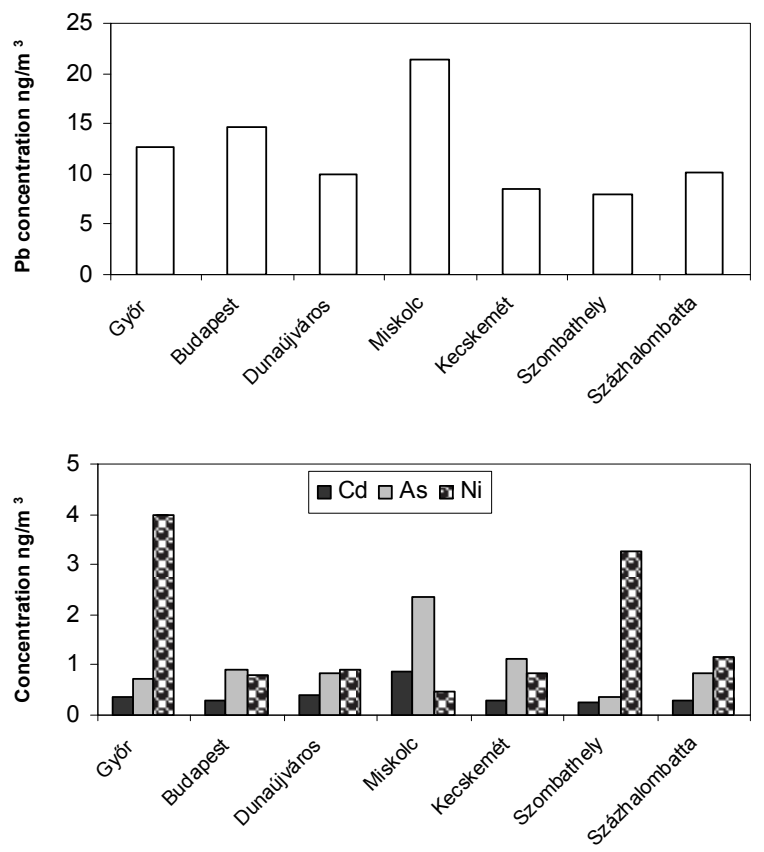

Figure 5. Trace metal(loid) annual average concentrations observed for Györ with other Hungarian cities in 2011

Although a direct comparison of literature data is difficult due to the analytical methods used, the different detection limits, the different sampling years and several other different factors such as urban or suburban population, traffic density, industrial activities, energy production, meteorological and atmospheric conditions, the concentrations of PM10 and trace elements in the urban area of Györ were also compared to the concentrations observed for published data of other cities around the 
world. The European cities listed in Table 3 have good air quality for PM10 compared to the other cities located in Asia or central and southern America. Györ has lower ambient metal(loid) concentrations than several other cities around the world listed in Table 3. The comparison of the data between the cities indicates that the pollution concentrations are strongly dependent on size of urban area and population, and economic potential, which are in a different order of magnitude.

Table 3. Comparison of the PM10 and measured trace metal(loid) concentrations of Györ with results obtained in other cities around the world

\begin{tabular}{|c|c|c|c|c|c|c|c|c|}
\hline \multirow{2}{*}{$\begin{array}{l}\text { Sampling } \\
\text { site }\end{array}$} & \multirow{2}{*}{$\begin{array}{l}\text { Type of } \\
\text { site }\end{array}$} & \multirow{2}{*}{$\begin{array}{l}\text { Sampling } \\
\text { year }\end{array}$} & \multirow[t]{2}{*}{ PM10 $\mu \mathrm{g} / \mathrm{m}^{3}$} & \multicolumn{4}{|c|}{ Trace elements $\mathrm{ng} / \mathrm{m}^{3}$} & \multirow[t]{2}{*}{ Reference } \\
\hline & & & & $P b$ & $C d$ & As & $\mathrm{Ni}$ & \\
\hline \multicolumn{9}{|l|}{ Europe } \\
\hline $\begin{array}{c}\text { Györ, } \\
\text { Hungary }\end{array}$ & Urban & 2011 & $\begin{array}{c}11-119.14 \\
47.43 \pm 31.65 \\
\end{array}$ & $\begin{array}{l}1.34-40.75 \\
12.61 \pm 8.77 \\
\end{array}$ & $\begin{array}{c}0.05-1.34 \\
0.38 \pm 0.2\end{array}$ & $\begin{array}{l}0.24-6.64 \\
0.74 \pm 1.07 \\
\end{array}$ & $\begin{array}{l}1.03-19.53 \\
3.97 \pm 2.71 \\
\end{array}$ & This study \\
\hline $\begin{array}{c}\text { Wien, } \\
\text { Austria }\end{array}$ & Urban & 2004 & $\begin{array}{l}8-124 \\
33 \pm 18 \\
\end{array}$ & $\begin{array}{c}2-77 \\
11 \pm 10 \\
\end{array}$ & $\begin{array}{l}0.1-1.5 \\
0.5 \pm 0.3 \\
\end{array}$ & $\begin{array}{l}0.2-16 \\
1.2 \pm 1.7 \\
\end{array}$ & $\begin{array}{c}0.2-51 \\
9.9 \pm 6.4 \\
\end{array}$ & [11] \\
\hline $\begin{array}{c}\text { Barcelona, } \\
\text { Spain }\end{array}$ & Urban & $1999-2000$ & $\begin{array}{c}20-119 \\
50 \\
\end{array}$ & $\begin{array}{c}22-467 \\
149 \\
\end{array}$ & ND & ND & $\begin{array}{c}1-38 \\
7 \\
\end{array}$ & [12] \\
\hline $\begin{array}{c}\text { Palermo, } \\
\text { Italy }\end{array}$ & Suburban & 2005 & $\begin{array}{c}11-83 \\
25 \\
\end{array}$ & $\begin{array}{c}1.8-32 \\
9.8 \\
\end{array}$ & ND & $\begin{array}{c}0.02-7.4 \\
1.8 \\
\end{array}$ & $\begin{array}{c}0.1-16 \\
4.6 \\
\end{array}$ & [13] \\
\hline $\begin{array}{l}\text { Venice, } \\
\text { Murano, } \\
\text { Italy }\end{array}$ & Industrial & $2001-2003$ & $\begin{array}{c}1.3-216 \\
45\end{array}$ & $\begin{array}{c}2.3-523 \\
161\end{array}$ & $\begin{array}{c}1.0-326.3 \\
170\end{array}$ & $\begin{array}{c}0.3-424 \\
181\end{array}$ & $\begin{array}{c}2.4-179 \\
74\end{array}$ & [14] \\
\hline $\begin{array}{c}\text { Basel, } \\
\text { Switzerland }\end{array}$ & Suburban & 1998-1999 & 24.8 & 21 & 0.03 & 0.44 & 2.2 & {$[15]$} \\
\hline $\begin{array}{l}\text { Athens, } \\
\text { Greece }\end{array}$ & Urban & $\begin{array}{c}\text { Summer / } \\
\text { winter } \\
2003\end{array}$ & $\begin{array}{c}13-25 \\
19 \pm 3 / \\
16-109 \\
56 \pm 25 \\
\end{array}$ & $\begin{array}{c}3.9-9 \\
6.4 \pm 1.5 / \\
4.6-36.7 \\
19.5 \pm 9.8 \\
\end{array}$ & $\begin{array}{c}0.05-1.07 \\
0.5 \pm 0.3 / \\
0.04-1.4 \\
0.3 \pm 0.4\end{array}$ & $\begin{array}{c}\mathrm{ND} / \\
8.5-38.1 \\
14.7 \pm 7.3\end{array}$ & $\begin{array}{c}3.5-45.1 \\
14.7 \pm 11.4 \\
2.2-14 \\
8.2 \pm 4 \\
\end{array}$ & {$[16]$} \\
\hline $\begin{array}{c}\text { Thessaloniki, } \\
\text { Greece }\end{array}$ & $\begin{array}{l}\text { Urban and } \\
\text { industrial }\end{array}$ & $\begin{array}{c}\text { Winter } \\
2006-2007\end{array}$ & $\begin{array}{c}29-237 \\
63 \pm 69\end{array}$ & $\begin{array}{c}7.65-163 \\
39.4\end{array}$ & $\begin{array}{c}0-84.8 \\
13.1 \\
\end{array}$ & $\begin{array}{c}0-35.9 \\
6.6\end{array}$ & $\begin{array}{c}0.43-67.5 \\
14.8 \\
\end{array}$ & [17] \\
\hline $\begin{array}{c}\text { Edinburgh, } \\
\text { UK }\end{array}$ & Urban & $1999-2000$ & $\begin{array}{c}7.3-29.1 \\
14.2 \\
\end{array}$ & $\begin{array}{c}1.28-130 \\
14.1 \\
\end{array}$ & $\begin{array}{c}0-10.1 \\
0.34 \\
\end{array}$ & $\begin{array}{c}0.13-1.49 \\
0.37 \\
\end{array}$ & $\begin{array}{c}0.89-37.9 \\
3.43 \\
\end{array}$ & [18] \\
\hline $\begin{array}{c}\text { Belgrade, } \\
\text { Serbia }\end{array}$ & Urban & $2003-2005$ & $\begin{array}{l}2.8-333.8 \\
68.4 \pm 46.4 \\
\end{array}$ & $\begin{array}{c}0.5-152.5 \\
46.5 \pm 128.5 \\
\end{array}$ & $\begin{array}{l}0-17.7 \\
1.4 \pm 2.2\end{array}$ & ND & $\begin{array}{l}0.4-107.7 \\
17.7 \pm 17.7 \\
\end{array}$ & [19] \\
\hline \multicolumn{9}{|l|}{ America } \\
\hline $\begin{array}{c}\text { Rio de } \\
\text { Janeiro, } \\
\text { Brazil }\end{array}$ & Suburban & $2004-2005$ & $\begin{array}{l}71-312 \\
169 \pm 42\end{array}$ & $\begin{array}{c}0-69 \\
15.9\end{array}$ & $\begin{array}{c}0-1.6 \\
0.4\end{array}$ & $\mathrm{ND}$ & $\begin{array}{c}0-7.6 \\
2.1\end{array}$ & {$[20]$} \\
\hline $\begin{array}{c}\text { Puebla City, } \\
\text { Mexico }\end{array}$ & Urban & 2008 & 199.2 & 38.4 & 2.76 & 22.5 & 13.3 & [21] \\
\hline $\begin{array}{c}\text { Costa Rica, } \\
\text { Central } \\
\text { America } \\
\end{array}$ & Urban & $2010-2011$ & $55 \pm 15$ & $11.5 \pm 3.9$ & ND & ND & $2.1 \pm 0.8$ & [22] \\
\hline $\begin{array}{c}\text { Tuscon, } \\
\text { Arizona, } \\
\text { USA }\end{array}$ & $\begin{array}{l}\text { Urban and } \\
\text { industrial }\end{array}$ & $2008-2009$ & $\begin{array}{l}1.5-152.9 \\
25.5 \pm 15.5\end{array}$ & $\begin{array}{l}0-12.1 \\
2.8 \pm 1.6\end{array}$ & $\begin{array}{c}0-4.8 \\
0.1 \pm 0.5\end{array}$ & $\begin{array}{c}0-6.2 \\
0.3 \pm 0.8\end{array}$ & $\begin{array}{c}0-23.4 \\
0.7 \pm 1.9\end{array}$ & [23] \\
\hline \multicolumn{9}{|l|}{ Asia } \\
\hline $\begin{array}{l}\text { Beijing, } \\
\text { China }\end{array}$ & Urban & $\begin{array}{c}\text { Summer / } \\
\text { winter } \\
2002-2003\end{array}$ & $\begin{array}{c}24-462 \\
172 \pm 102 / \\
29-446 \\
184 \pm 131\end{array}$ & $\begin{array}{c}\text { ND } \\
110 \pm 90 / \\
\text { ND } \\
370 \pm 370\end{array}$ & $\begin{array}{c}\mathrm{ND} \\
2.4 \pm 2.8 / \\
\mathrm{ND} \\
15.2 \pm 20.6\end{array}$ & $\begin{array}{c}\text { ND } \\
20 \pm 20 / \\
\text { ND } \\
60 \pm 70\end{array}$ & $\begin{array}{c}\text { ND } \\
40 \pm 30 / \\
\text { ND } \\
110 \pm 110\end{array}$ & {$[24]$} \\
\hline $\begin{array}{l}\text { Taj Mahal, } \\
\text { Agra, India }\end{array}$ & $\begin{array}{l}\text { Suburban } \\
\text { and } \\
\text { industrial }\end{array}$ & $2007-2008$ & $\begin{array}{l}31-362 \\
155 \pm 78\end{array}$ & $\begin{array}{l}0-109 \\
26 \pm 22\end{array}$ & $\begin{array}{c}0-52.9 \\
23.5 \pm 11.9\end{array}$ & $\begin{array}{l}0-220 \\
50 \pm 40\end{array}$ & $\begin{array}{l}0-150 \\
50 \pm 30\end{array}$ & [25] \\
\hline Seoul, Korea & $\begin{array}{l}\text { Urban and } \\
\text { industrial }\end{array}$ & 2002 & $\begin{array}{c}18-279 \\
79 \pm 60\end{array}$ & $\begin{array}{l}39-401 \\
200 \pm 97\end{array}$ & $\begin{array}{c}2.2-30.4 \\
5.5 \pm 6.7\end{array}$ & ND & $\begin{array}{c}0.3-313 \\
46 \pm 87\end{array}$ & {$[26]$} \\
\hline
\end{tabular}

ND: No Data 
A summary report on air quality in Europe [3] has highlighted that the EU limit values for PM10 were exceeded widely in 2011 according to the data of the European air quality database. The annual limit value for PM10 was exceeded most often in Poland, Italy, Slovakia, the Balkan region, Turkey and also in several urban regions. The daily limit value was exceeded in other cities in those countries, as well as in many other countries in central, western and southern Europe. Cities in Latvia, Sweden and the United Kingdom also exceeded the daily limit value for PM10. However, the human exposure to $\mathrm{Pb}, \mathrm{Cd}, \mathrm{As}$, and $\mathrm{Ni}$ ambient air concentrations above the limit or target values is a local problem, and typically caused by specific industrial plants.

\section{Conclusions}

The concentrations of PM10 and the most monitored and regulated airborne particulate trace metal(loid)s ( $\mathrm{Pb}, \mathrm{Cd}$, As and $\mathrm{Ni}$ ) were determined in an urban site of Györ during four sampling periods in 2011. The annual average concentration of PM10 indicates a polluted area. However, the concentrations of PM10 exhibit large variability during the sampling periods. The PM10 levels indicate excellent or good air quality in the sampling periods without heating. Levels of airborne metal(loid)s in Györ area were relatively low, similar to the values reported for not polluted cities. The annual average concentrations of each trace element were below the EU and the Hungarian air quality standards.

\section{Acknowledgement}

We are indebted to József Erdős, István Vass, Bálint Kauker, Zsuzsanna Károly Némethné, Tünde Takács Kovácsné, Lajosné Bakódy and Péter Lautner (North Transdanubian Regional Environmental Protection and Nature Conservation Inspectorate Laboratory, Hungary) for chemical analyses, data and site information. We also thank József Erdős for field support.

\section{References}

[1] WHO: Air quality guidelines for Europe, World Health Organization, Regional Office for Europe, Copenhagen, 2000

[2] WHO: WHO air quality guidelines, global update 2005, World Health Organization; Regional Office for Europe, Copenhagen, 2005

[3] EEA: Air quality in Europe - 2013 report, European Environment Agency, Luxembourg, 2013

[4] Johansson, C., Norman, C., Burnan, L.: Road traffic emission factors for heavy metals, Atmospheric Environment, vol. 43, no. 31, pp. 4681-4688, 2009

DOI: 10.2181/036.043.0202

[5] Gaffney, J.S., Marley, N.A.: The impacts of combustion emissions on air quality and climate - from coal to biofuels and beyond, Atmospheric Environment, vol. 43, no. 1, pp. 23-36, 2009

DOI: $10.1016 / \mathrm{j}$.atmosenv.2008.09.016

[6] Digitel Electronic AG: Digitel high volume aerosol sampler, Manual, Hegnau, Switzerland, 2010 
[7] EN 12341: Air quality - Determination of the PM10 fraction of suspended particulate matter - Reference method and field test procedure to demonstrate reference equivalence of measurement methods, 1998

[8] MSZ EN 14902:2006: Ambient air quality. Standard method for the measurement of Pb, $\mathrm{Cd}$, As and Ni in the PM10 fraction of suspended particulate matter (in Hungarian)

[9] 4/2011 (I.14.) VM.: Guidelines for the air load levels and the stationary point source emissions (in Hungarian)

[10] OMSZ ÉLFO: Summary of the OLM PM10 sampling program in 2011, Reference Centre for Air Quality Protection, 2012 (in Hungarian)

[11] Limbeck, A., Handler, M., Puls, C., Zbiral, J., Bauer,Puxbaum, H.: Impact of mineral components and selected trace metals on ambient PM10 concentrations, Atmospheric Environment, vol. 43, pp. 530-538, 2009

DOI: 10.1016/j.atmosenv.2008.10.012

[12] Querol, X., Alastuey, A., Rodriguez, S., Plana, F., Ruiz, C.R., Cots, N., Massague, G., Puig, O.: PM10 and PM2.5 source apportionment in the Barcelona Metropolitan area, Catalonia, Spain, Atmospheric Environment, vol. 35, no. 36, pp. 6407-6419, 2001

DOI: $10.1016 / \mathrm{S} 1352-2310(01) 00361-2$

[13] Dongarra, G., Manno, E., Varrica, D., Vultaggio, M.: Mass levels, crustal component and trace elements in PM10 in Palermo, Italy, Atmospheric Environment, vol. 41, pp. 79777986, 2007

DOI: 10.1016/j.atmosenv.2007.09.015

[14] Rossini, P., Matteucci, G., Guerzoni, S.: Atmospheric fall-out of metals around the Murano glass-making district (Venice, Italy), Environmental Science and Pollution Research, vol. 17 , no. 1 , pp. 40-48, 2010

DOI: $10.1007 / \mathrm{s} 11356-009-0122-8$

[15] Hueglin, C., Gehrig, R., Baltensperger, U., Gysel, M., Monn, C., Vonmont, H.: Chemical characterisation of PM2.5, PM10 and coarse particles at urban, near-city and rural sites in Switzerland, Atmospheric Environment, vol. 39, pp. 637-651, 2005

DOI: 10.1016/j.atmosenv.2004.10.027

[16] Vassilakos, C., Veros, D., Michopoulos, J., Maggos, T., O' Connor, C.M.: Estimation of selected heavy metals and arsenic in PM10 aerosols in the ambient air of the Greater Athens Area, Greece, Journal of Hazardous Materials, vol. 140, no. 1-2, pp. 389-398, 2007 DOI: 10.1016/j.jhazmat.2006.11.002

[17] Terzi, E., Argyropoulos, G., Bougatioti, A., Mihalopoulos, N., Nikolaou, K., Samara, C.: Chemical composition and mass closure of ambient PM10 at urban sites, Atmospheric Environment, vol. 44, no.18, pp. 2231-2239, 2010

DOI: $10.1016 / \mathrm{j}$. atmosenv.2010.02.019

[18] Heal, M.R., Hibbs, L.R., Agius, R.M., Beverland, I.J.: Total and water soluble trace metal content of urban background PM10, PM2.5 and Black Smoke in Edinburgh, UK, Atmospheric Environment, vol. 39, pp. 1417-1430, 2005

DOI: 10.1016/j.atmosenv.2004.11.026

[19] Rajšić, S., Mijić, Z., Tasić, M., Radenković, M., Joksić, J.: Evaluation of the levels and sources of trace elements in urban particulate matter, Environmental Chemistry Letters, vol. 6, no. 2, pp. 95-100, 2008

DOI: $10.1007 / \mathrm{s} 10311-007-0115-0$

[20] Toledo, V.E., Almeida, P.B., Quiterio, S.L., Arbilla, G., Moreira, A., Escaleira, V., Moreira, J.C.: Evaluation of levels, sources and distribution of toxic elements in PM10 in a suburban industrial region, Rio de Janeiro, Brazil, Environmental Monitoring and Assessment, vol. 139, no. 1-3, pp. 49-59, 2008

DOI: $10.1007 / \mathrm{s} 10661-007-9815-\mathrm{y}$

[21] Morales-Garcia, S. S., Rodriguez-Espinosa, P. F., Jonathan, M. P., Navarrete-Lopez, M., Herrera-Garcia, M. A., Munoz-Sevilla, N. P.: Characterization of As and trace metals 
embedded in PM10 particles in Puebla City, Mexico, Environmental Monitoring and Assessment, vol. 186, no. 1, pp. 55-67, 2014

DOI: $10.1007 / \mathrm{s} 10661-013-3355-4$

[22] Murillo, J. H., Roman, S. R., Marin, J. F. R., Ramos, A. C., Jimenez, S. B., Gonzales, B. C., Baumgardner, D. G.: Chemical characterization and source apportionment of PM10 and PM2.5 in the metropolitan area of Costa Rica, Central America, Atmospheric Pollution Research, vol. 4, no. 2, pp. 181-190, 2013

DOI: $10.5094 / A P R .2013 .018$

[23] Foley, T., Betterton, E. A., Wolf, A.: Ambient PM10 and Metal Concentrations Measured in the Sunnyside Unified School District, Tucson, Arizona, Journal of the Arizona-Nevada Academy of Science, vol. 43, no. 2, pp. 67-76, 2012

DOI: $10.2181 / 036.043 .0202$

[24] Sun, Y., Zhuang, G., Wang, Y., Han, L., Guo, J., Dan, M., Zhang, W., Hao, Z.: The airborne particulate pollution in Beijing - concentration, composition, distribution and sources, Atmospheric Environment, vol. 38, pp. 5991-6004, 2004

DOI: 10.1016/j.atmosenv.2004.07.009

[25] Singh, R., Sharma, B.S.: Composition, seasonal variation and sources of PM10 from world wide heritage site Taj Mahal, Agra, Environmental Monitoring and Assessment, vol. 184, no. 1-3, pp. 5945-5956, 2012

DOI: $10.1007 / \mathrm{s} 10661-011-2392-0$

[26] Kim, K.H., Mishra, V.K., Kang, C.H., Choi, K.C., Kim, Y.J., Kim, D.S., Youn, Y.H., Lee, J.H.: The metallic composition of aerosols at three monitoring sites in Korea during winter 2002, Environmental Monitoring and Assessment, vol. 121, no. 1-3, pp. 381-399, 2005 DOI: $10.1007 / \mathrm{s} 10661-005-9136-\mathrm{y}$ 